\title{
Influence of nicotine on machined- and anodized-surface implants. Histometric analysis
}

\author{
Maria-Salete-Sandini Linden 1, Luiz-Renato Paranhos ${ }^{2}$, João-Paulo De Carli 1, Micheline-Sandini Trentin ${ }^{1}$, \\ Marcos-Eugênio de Bittencourt ${ }^{1}$, Pâmela-Letícia Santos ${ }^{3}$, Francisco-Carlos Groppo ${ }^{4}$, Juliana-Camma Ra- \\ macciato $^{5}$ \\ ${ }^{1}$ DDS, MSc, PhD, Professor, Department of Dentistry. University of Passo Fundo, Passo Fundo, RS, Brazil \\ ${ }^{2}$ Professor, Department of Dentistry. Federal University of Sergipe, Lagarto, SE, Brazil \\ ${ }^{3}$ Professor, Oral Biology Postgraduate Program, Sagrado Coração University, Bauru, SP, Brazil \\ ${ }^{4}$ Professor, Department of Physiological Sciences. State University of Campinas, Piracicaba, SP, Brazil \\ ${ }^{5}$ Professor, Department of Dentistry. Faculty SL Mandic, Campinas, SP, Brazil
}

Correspondence:

Post-Graduation Department

Sagrado Coração University

Irmã Arminda, 10-50. Jardim Brasil

Bauru - São Paulo Brazil - 17011-160

pamelalsantos@hotmail.com

Received: 10/06/2017

Accepted: 09/08/2017

\begin{abstract}
Linden MSS, Paranhos LR, De Carli JP, Trentin MS, de Bittencourt ME, Santos PL, Groppo FC, Ramacciato JC. Influence of nicotine on machined- and anodized-surface implants. Histometric analysis. J Clin Exp Dent. 2017;9(10):e1207-11.

http://www.medicinaoral.com/odo/volumenes/v9i10/jcedv9i10p1207.pdf
\end{abstract}

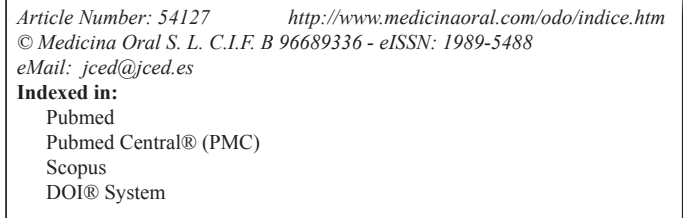

\begin{abstract}
Background: The nicotine may generate a influence on bone repair and longevity of dental implants. This fact makes studies to improve the surface of the implants are constantly conducted. This study aimed to evaluate the influence of subcutaneous nicotine injection in the osseointegration process on different implant surfaces, through histomorphometric analysis.

Material and Methods: Therefore, twenty-two male rabbits were randomly distributed into two groups according to the subcutaneous injections: (1) nicotine, $3 \mathrm{mg} / \mathrm{day} / \mathrm{kg}$ and (2) $0.9 \% \mathrm{NaCI}, 3 \mathrm{~mL} / \mathrm{day} / \mathrm{kg}$, three times a day. Subgroups were then designated - machined and anodized dental implants were installed in the right and left tibia bones, respectively. The animals were subjected to euthanasia after periods of eight weeks for histomorphometric analysis. The bone samples with implants were removed and the routine histological processing was performed. Next, the images obtained from the blades were evaluated by the Image Tool ${ }^{\mathrm{TM}}$ software, assessing the osseointegrated areas of implants (BIC), in pixels. Data obtained were subjected to intergroup statistical analysis through the Kruskal-Wallis non-parametric test $(\alpha=5 \%)$.

Results: The test result showed no statistically significant difference among the groups studied ( $p=0.446$ ).

Conclusions: Based on the methodology studied, it is concluded that the daily application of low doses of nicotine did not interfere with the osseointegration of machined and anodized implants.
\end{abstract}

Key words: Bone-implant interface, implants, osseointegration. 


\section{Introduction}

Dental implants are predictable when bone quantity and quality are adequate. However, this is often not the case, such as in patients who smoke, where the areas of cancellous bone and lamellar cortical bone are thin (1).

Some studies report that nicotine may cause tissue ischemia and reduce vascular internal growth, and that these facts generate a negative influence on bone repair and longevity of dental implants (2-6).

Based on these challenges, implants are constantly being improved, especially regarding their surfaces, which favor higher adhesiveness of osteoblasts and consequent bone neoformation around implants, improving the prognosis for complex clinical situations (7-9). Anodized-surface implants have shown higher values of bone/ implant contacts and of removal torque when compared to machined-surface implants (10-15).

Thus, the present study aimed to investigate, through the histometry in animal models, whether the use of daily nicotine injection for eight weeks may influence the osseointegration of titanium implants with treated (anodized) or untreated surface.

\section{Material and Methods}

\section{-Animals}

The study was reviewed and approved by the Ethics Committee of the University of Passo Fundo (n.535/2006), RS, Brazil. Twenty-two ( $\mathrm{n}=44$ tibia) adult male New Zealand white rabbits (Oryctolagus cuniculus) weighing 3.5 to $4.0 \mathrm{~kg}$, aged 8 to 10 months were used. All rabbits were housed in animal facilities at $25^{\circ} \mathrm{C}$, in 12 -hour light/dark cycles. Throughout the experimental period, the rabbits were housed in individual plastic cages and a normal chow diet and water were provided ad libitum.

The animals were randomly distributed into two groups: Control Group - animals received subcutaneous injection of $0.9 \% \mathrm{NaCI}, 3 \mathrm{~mL} / \mathrm{Kg} /$ day, three times a day for eight weeks ( $\mathrm{n}=22)$; Test Group - animals received subcutaneous injections of $98 \%$ nicotine hydrogen tartrate salt (SigmaAldrich, Copenhagen, Denmark A/S), $3 \mathrm{mg} / \mathrm{kg} /$ day, three times a day $(\mathrm{n}=22)(15)$. Each group was then divided into two subgroups - machined and anodized dental implants corresponding to the dental implant used, respectively.

-Surgical Procedure

The animals received atropine $(0.50 \mathrm{mg}-0.44 \mathrm{mg} /$ $\mathrm{kg} / \mathrm{i} . \mathrm{p}),$.15 minutes before surgery. General anesthesia was administered by an intramuscular injection of $2 \%$ xylazine hydrochloride, $5 \mathrm{mg} / \mathrm{kg}$ (Rompun; Bayer, São Paulo, Brazil) and $7 \mathrm{mg} / \mathrm{kg}$ of tiletamine (zolazepan/zoletil - Virbac do Brasil Indústria e Comércio Ltda).

Experimental surgery for implant installation was performed as previously described (16). Then, trichotomy and antisepsis were performed in each tibia with iodine solution (10\% PVPI, Riodeine Degermante, Rioquímica, SP, Brazil) and topical PVPI before surgical incision.
Local anesthesia was performed by infiltrative injection with $2 \%$ mepivacaine $\left(0.3 \mathrm{~mL} / \mathrm{kg}, 2 \%\right.$ Scandicaine $^{\mathrm{TM}}$ with adrenalin 1:100.000, Septodont, France).

A careful surgical technique was performed with a $3-\mathrm{cm}$ long incision on the proximal tibia just below the knee to the depth of the bone tissue. The soft tissue was carefully dissected and lifted with the aid of a periosteal elevator, exposing the bone tissue for implant insertion. After pre-threading the receptor site, implants were inserted in each proximal metaphysis, under $40 \mathrm{~N}$ of torque.

One machined-surface implant (Master Screw ${ }^{\mathrm{TM}}$ ) in the right tibia and one anodized-surface implant (Master Vulcano Actives ${ }^{\mathrm{TM}}$ ) in the left one were installed in each animal. Both implants had $3.75 \mathrm{~mm}$ of diameter, were 6-mm long, and screw-shaped with external hexagon (ASTM grade 4). Both implants were provided by Conexão Sistemas de Prótese (São Paulo, SP, Brazil). Soft tissues were replaced and sutured.

After suturing, intramuscular pentabiotic $(0.1 \mathrm{~mL} / \mathrm{kg}$, Fort Dodge Saúde Animal Ltda, SP, Brazil) was performed immediately and at 5 days postoperatively. Sodium dipyrone $(1 \mathrm{mg} / \mathrm{kg} /$ day, Ariston Indústrias Químicas e Farmacêuticas Ltda, São Paulo, SP, Brazil) was also administered. Neither food nor movement restriction was applied to the animals that remained in individual cages during the experimental period. All rabbits were euthanized by a lethal dose of pentobarbital $(200 \mathrm{mg} / \mathrm{kg})$ at 8 weeks after surgery.

-Histomorphometric analysis

The tissue samples (bone/implant interface) were removed and placed in $10 \%$ neutral buffered formalin. Then, these samples were dehydrated in increasing concentrations of ethanol (60-100\%) and later infiltrated in lightcuring resin (Technovit 7200 VLC, Kultzer Heraeus GmbH \& Co., Wehrheim, Germany).

The blocks with implant and peri-implant bone tissue were cut in a central point through a cutting and wear system (Phenom Prox ${ }^{\mathrm{TM}}$, Anacom Científica, Araraqua$\mathrm{ra}$, SP, Brazil). The blades were obtained with approximate thickness of $50 \mu \mathrm{m}$.

The images were analyzed in a light microscope (DIASTAR, Leica Reichert \& Jung products, Germany) and captured through a Leica Microsystems DFC-300-FX digital camera (Leica Microsystems, Germany), with 1.3 megapixels of resolution, coupled to a regular light microscope and a computer.

The histometric analyses were performed with the image analysis software "Image Tool" (Fig. 1). The linear extension of bone tissue and implant surface (BIC) was calculated in pixels among the 3 most coronary loops (located in the cortical bone) in each side of the implant.

The BIC levels were compared intra- and intergroup. Data obtained in each type of comparison were subjected to statistical analysis through the Kruskal-Wallis non-parametric test $(\alpha=5 \%)$. 


\section{Results}

Table 1 and Figure 2 show the perimeter of the osseointegrated implant surface for each group studied, in pixels, as well as mean and standard deviation. The Kruskal-Wallis non-parametric test was applied and showed no statistically significant difference among the groups studied ( $p=0.446)$. However, group $2 /$ anodized was likely to higher osseointegration when compared to the other groups.
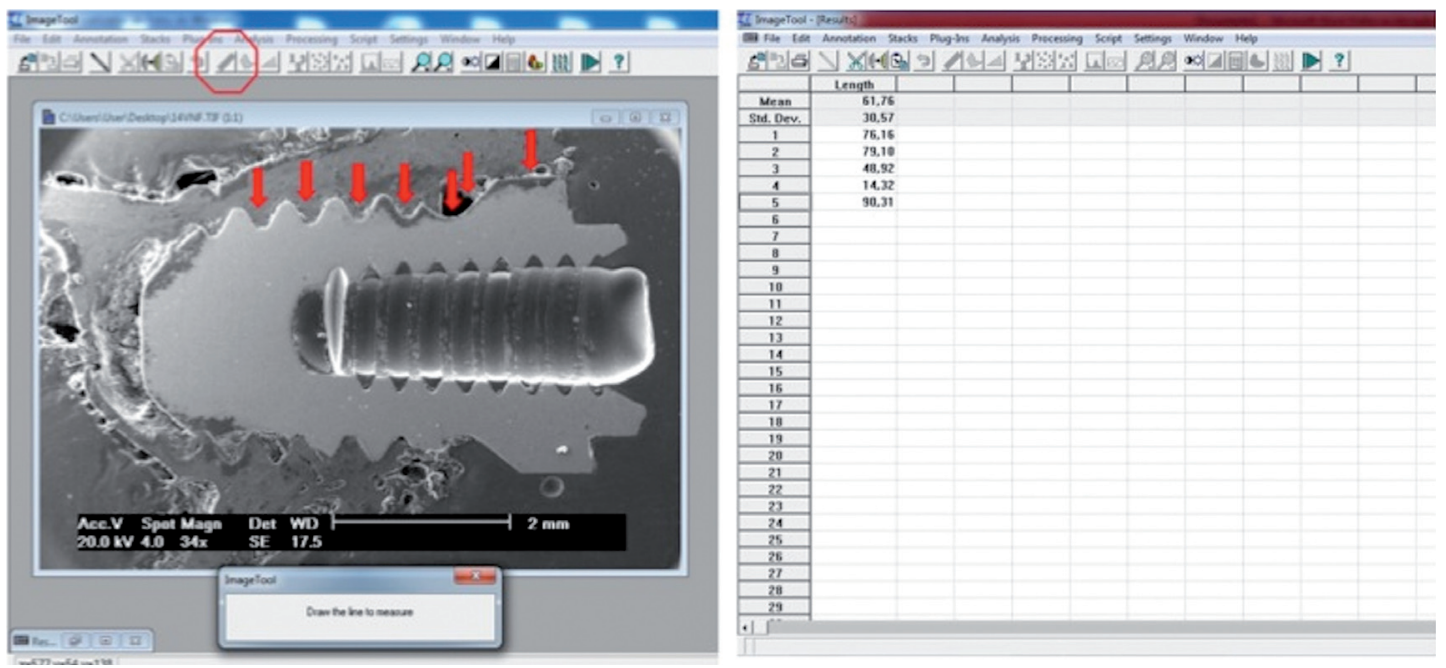

Fig. 1: Image of a machined implant inserted in bone tissue that received nicotine, assessed in the Image Tool ${ }^{\mathrm{TM}}$ software (red arrows) by the "Distance" tool (circle), and bellow is the spreadsheet with automatically generated lengths, added up at the end of assessment.

Table 1: Perimeter of osseointegrated implant surfaces (in pixels) of the groups studied.

\begin{tabular}{|c|c|c|c|c|}
\hline Groups/ Animals & $\begin{array}{c}\text { Group 1/ Machined } \\
\text { (Pixels) }\end{array}$ & $\begin{array}{c}\text { Group 1/ Anodized } \\
\text { (Pixels) }\end{array}$ & $\begin{array}{c}\text { Group 2/ Machined } \\
\text { (Pixels) }\end{array}$ & $\begin{array}{c}\text { Group 2/ Anodized } \\
\text { (Pixels) }\end{array}$ \\
\hline $\mathbf{1}$ & 160543 & 65104 & 17063 & 127145 \\
\hline $\mathbf{2}$ & 117903 & 134479 & 162044 & 147092 \\
\hline $\mathbf{3}$ & 151442 & 129435 & 97068 & 146558 \\
\hline $\mathbf{4}$ & 147097 & 138075 & 174157 & 149233 \\
\hline $\mathbf{5}$ & 147676 & 120484 & 6536 & 131617 \\
\hline $\mathbf{6}$ & 132070 & 179632 & 121908 & 131188 \\
\hline $\mathbf{7}$ & 146151 & 122034 & 122286 & 155608 \\
\hline $\mathbf{8}$ & 7409 & 100957 & 122086 & 137873 \\
\hline Mean \pm SD & $126282 \pm 46039$ & $123775 \pm 30512$ & $122089 \pm 54303$ & $140789 \pm 9584$ \\
\hline
\end{tabular}

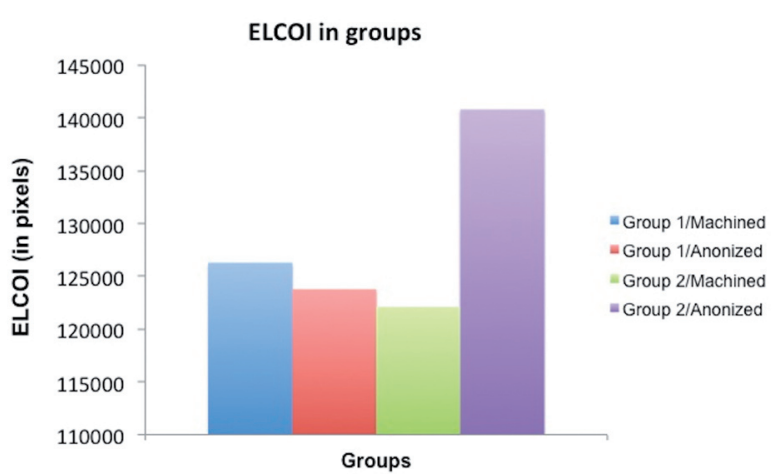

Fig. 2: Graphic representation of mean values of BIC for each group (in pixels).

\section{Discussion}

This study analyzed the influence of nicotine around osseointegrable implants, through histomorphometric analysis, on machined- and anodized-surface implants. The results showed that nicotine and implant surface had no negative effect on osseointegration.

These results corroborate experimental researches previously performed (1,17-19), which detected no negative impact of nicotine on the repair process. However, other authors (2-6) reported that nicotine causes tissue ischemia and reduces vascular internal growth with consequent negative effect on bone repair and the longevity of dental implants. Kallala et al. (20) confirm that 
the effect of nicotine is dose-dependent, meaning that it presents negative effects in high concentrations, while showing stimulant effects in low concentrations.

Although humans chronically inhale cigarette smoke and the bone tissue is exposed to its components for years, some authors (21-22) showed that studies in rabbits testing daily nicotine injections are relevant. Hence, César Neto et al. (23) compared only cigarette smoke and nicotine and found that the latter alone did not present the deleterious effects of the cigarette smoke, especially on medullary bone, concluding that the adverse effects of cigarette smoking on implant success may be reported only if the cigarette is considered along with all its components (24).

When considering other studies conducted in animals $(1,17-18)$, it is found that they did not detect an impact on mineral bone density of female rats after two years of nicotine exposure. Such findings are added to the present study, which did not find differences in the osseointegration area among the groups that received and did not receive nicotine.

On the other hand, Kumar et al. (25) affirm that smoking is related to lower bone density and that the poor bone quality observed in smokers may lead to inadequate primary bone stability, resulting in excessive mobility and implant failure. However, their retrospective study showed no statistically significant difference of bone quality between smokers and non-smokers. Thus, we prevail by the findings by Akhter et al. (26), which hypothesized other tobacco agents as responsible for the decrease in bone density and increase in the risk of fracture observed in smokers.

Anodized implants are characterized by the presence of thick heterogeneous oxide, promoting a slightly increased bone response, especially in the first weeks after implantation, as affirmed by previous studies (1011,14,27).

Peñarrocha et al. (28) showed that titanium implants with rough surface presented higher bone loss in smokers than in non-smokers, especially when installed in the maxilla. Corroborating this, Shibli et al. (29) performed a prospective study assessing the impact of smoking on bone-implant contact and bone density in treated and untreated implant areas, using anodized-surface implants, in humans. These authors concluded that the smoking habit in humans presents a deleterious effect on early bone response of the implants studied.

On the other hand, Kumar et al. (25) performed a research where the rates of bone loss were similar for implants with rough surface, both in smokers and non-smokers. As for Bain et al. (30), they found no differences between groups of smokers and non-smokers, monitoring machined-surface and textured-surface implants. Corroborating these studies, the present research found no influence of nicotine and implant surface on osseointegration.
From the aforementioned, it is agreed that basic scientific information on the bone repair mechanism, in response to implant installation, are always relevant. However, clinical studies are welcome to assess the long-term dynamic bone response using several materials and implant surfaces associated to risk factors such as smoking. The subcutaneous application of low doses of nicotine had no negative influence on the osseointegration of machined and anodized implants.

\section{References}

1. Syversen U, Nordsletten L, Falch JA, Madsen JE, Nilsen OG, Waldum HL. Effect of lifelong nicotine inhalation on bone mass and mechanical properties in female rat femurs. Calcif Tissue Int. 1999;65:246-9.

2. Wallace RH. The relationship between cigarette smoking and dental implant failure. Eur J Prosthodont Restor Dent. 2000;8:103-6.

3. Vehemente VA, Chuang SK, Daher S, Muftu A, Dodson TB. Risk factors affecting dental implant survival. J Oral Implantol. 2002;28:7481.

4. McDermott NE, Chuang SK, Woo VV, Dodson TB. Complications of dental implants: identification, frequency, and associated risk factors. Int J Oral Maxillofac Implants. 2003;18:848-55.

5. Kourtis SG, Sotiriadou S, Voliotis S, Challas A. Private practice results of dental implants. Part I: survival and evaluation of risk factors- Part II: surgical and prosthetic complications. Implant Dent. 2004; 13:373-85.

6. Moy PK, Medina D, Shetty V, Aghaloo TL. Dental implant failure rates and associated risk factors. Int J Oral Maxillofac Implants. 2005;20:569-77.

7. Xiropaidis AV, Qahash M, Lim WH, Shanaman RH, Rohrer MD, Wikesjö UM, et al. Bone-implant contact at calcium phosphate-coated and porous titanium oxide (Ti Unite)-modified oral implants. Clin Oral Impl Res. 2005;16:532-9.

8. Glauser R, Portmann M, Ruhstaller P, Allan B, Johansson C, Hall J. Stability measurements of immediately loaded machined and oxidized implants in the posterior maxilla. A comparative clinical study using resonance frequency analysis. Appl Oss Res. 2001;2:27-9.

9. Glauser R, Gottlow J, Lundgren AK, Sennerby L, Portmann M, Ruhstaller P, et al. Immediate occlusal loading of Branemark MkIV TiUniteTM implants placed in bone quality 4. Appl Osseointegration Res. 2003;3:22-4.

10. Albrektsson T, Johansson C, Lundgren AK, Sul Y, Gottlow J. Experimental studies on oxidized implants. A histomorphometric and biomechanical analysis. Appl Osseointegration Res. 2001;1:21-4.

11. Sul YT. The significance of the surface properties of oxidized titanium to the bone response: special emphasis on potential biochemical bonding of oxidized titanium implant. Biomaterials. 2003;24: 3893907.

12. Rocci A, Martignoni M, Gottlow J. Immediate loading of Branemark System ${ }^{\circledR}$ TiUniteTM and machined-surface implants in the posterior mandible: a randomized open-ended clinical trial. Clin Implant Dent Related Res. 2003;5:57-63.

13. Palma VC, Magro-Filho O, Oliveria JA, Lundgren S, Salata LA, Sennerby L. Bone reformation and implant integration following maxillary sinus membrane elevation: an experimental study in primates. Clin Implant Dent Relat Res. 2006;8:11-24.

14. Shibli JA, Grassi S, Figueiredo LC, Feres M, Iezzi G, Piattelli A. Human peri-implant bone response to turned and oxidized titanium implants inserted and retrieved after 2 months. Implant Dent. 2007;16:252-9.

15. Duygulu F, Karaoğlu S, Zeybek ND, Kaymaz FF, Güneş T. The effect of subcutaneously injected nicotine on achilles tendon healing in rabbits. Knee Surg Sports Traumatol Arthrosc. 2006;14:756-61.

16. Santos PL, Molon RS, Queiroz TP, Okamoto R, de Souza Faloni AP, Gulinelli JL. Evaluation of bone substitutes for treatment of peri-implant bone defects: biomechanical, histological, and immuno- 
histochemical analyses in the rabbit tibia. J Periodontal Implant Sci. 2016;46:176-96.

17. Iwaniec UT, Fung YK, Akhter MP, Haven MC, Nespor S, Haynatzki GR. Effects of nicotine on bone mass, turnover, and strength in adult female rats. Calcif Tissue Int. 2001;68:358-64.

18. Iwaniec UT, Fung YK, Cullen DM, Akhter MP, Haven MC, Schmid M. Effects of nicotine on bone and calciotropic hormones in growing female rats. Calc Tissue Int. 2000;67:68-74.

19. Balatsouka D, Gotfredsen K, Lindh CH, Berglundh T. The impact of nicotine on bone healing and osseointegration: An experimental study in rabbits. Clin Oral Implants Res. 2005;16:268-76.

20. Kallala R, Barrow J, Graham SM, Kanakaris N, Giannoudis PV. The in vitro and in vivo effects of nicotine on bone, bone cells and fracture repair. Expert Opin Drug Saf. 2013;59:211-218.

21. Nociti Jr FH, Cesar Neto JB, Carvalho MD, Sallum EA. Bone density around titanium implants may be influenced by intermittent cigarette smoke inhalation: a histometric study in rats. Int J Oral Maxillofac Implants. 2002; 17(3): 347-52.

22. Stefani CM, Nogueira F, Sallum EA, Sallum AW, Nociti FH Jr. Influence of nicotine administration on different implant surfaces: a histometric study in rabbits. J Periodontol. 2002;73:206-12.

23. César-Neto JB, Duarte PM, Sallum EA, Barbieri D, Moreno H Jr, Nociti FH Jr. A comparative study on the effect of nicotine administration and cigarette smoke inhalation on bone healing around titanium implants. J Periodontol. 2003;74:1454-9.

24. Peacock ME, Sutherland DE, Schuster GS, Brennan WA, O’Neal $\mathrm{RB}$, Strong SL, et al. The effect of nicotine on reproduction and attachment of human gingival fibroblasts in vitro. J Periodontol. 1993;64:658-65.

25. Kumar A, Jaffin RA, Berman C. The effect of smoking on achieving osseointegration of surface-modified implants: a clinical report. Int J Oral Maxillofac Implants. 2002;17:816-9.

26. Akhter MP, Iwaniec UT, Haynatzki GR, Fung YK, Cullen DM, Recker RR. Effects of nicotine on bone mass and strength in aged female rats. J Orthop Res. 2003; 21:14-9.

27. Larsson C, Emanuelsson L, Thomsen P, Ericson LE, Aronsson BO, Kasemo B, et al. Bone response to surface modified titanium implants - studies on the tissue response after 1 year to machined and electropolished implants with different oxide thicknesses. J Mater Sci Mater Med. 1997;8:721-9.

28. Pe-arrocha M, Palomar M, Sanchis JM, Guarinos J, Balaguer J. Radiologic study of marginal bone loss around 108 dental implants and its relationship to smoking, implant location, and morphology. Int J Oral Maxillofac Implants. 2004;19:861-7.

29. Shibli JA, Piattelli A, Iezzi G, Cardoso LA, Onuma T, de Carvalho PS, et al. Effect of smoking on early bone healing around oxidized surfaces: a prospective, controlled study in human jaws. J Periodontol. 2010;81:575-83.

30. Bain CA, Weng D, Meltzer A. A meta-analysis evaluating the risk for implant failure in patients who smoke. Compend Contin Educ Dent. 2002;23:695-9.

\section{Conflicts of Interest}

The authors declare that they have no conflict of interest. 